Б. В. Аергалюк,

к. е.н., дочент, дочент кафедри економіки і підприємниитва, Начіональний технічний університет Украйни "Київський політехнічний інститут імені Ігоря Сікорсъкого"

ORCID ID: 0000-0001-8791-9121

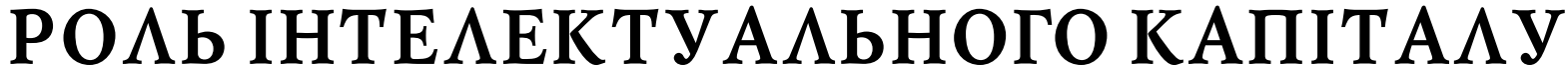 АИЯ ЗАІЙСНЕННЯ СТРУКТУРНОЇ MOАЕРНІЗАЦIÏ РЕГIOHААЬНӦ̈ ЕКОНОМIKИ
}

\author{
B. Dergaliuk, \\ $\mathrm{PhD}$ in Economics, Associate professor, Associate professor of economics and entrepreneurship department, \\ National technical university of Ukraine "Igor Sikorsky Kiev polytechnic institute"
}

\section{THE ROLE OF INTELLECTUAL CAPITAL FOR STRUCTURAL MODERNIZATION} OF THE REGIONAL ECONOMY

У статті обгрунтовано детермінуюче значення інтелектуального капіталу для здійснення структурної модернізації регіональної економіки. 3 'ясовано, щодо причин необхідності структурної модернізації регіональної економіки відносяться: зміна ціннісних орієнтирів у системі споживчих потреб під впливом масових суспільних явищ або досягнень науково-технічного прогресу; якісні зміни матеріально-технічної бази виробництва під впливом інтенсифікації інноваційних процесів; вплив процесів ринкового саморегулювання; вплив наявних структурних зрушень або структурних зрушень, які мали місце у минулому; глобальні тенденції до лібералізації зовнішньоекономічних взаємодій між державами тощо. Окреслено, що метою структурної модернізації регіональної економіки виступає прискорення економічного розвитку регіонів, підвищення ефективності регіональної господарської діяльності та рівня життя населення. Визначено, що структурна модернізація регіональної економіки спирається на притаманні властивості конкретного регіону та має певні пов'язані з цим ознаки. Виявлено особливості, на яких базується структурна модернізація регіональної економіки. Оскільки сучасні виклики доводять необхідність пошуку напрямів активізації інтелектуального потенціалу регіонів для забезпечення структурної модернізації регіональної економіки, обгрунтовано детермінуючє значення інтелектуального потенціалу регіону у структурній модернізації. Виокремлено чинники впливу на формування інтелектуального капіталу регіонів, серед яких: природно-ресурсний потенціал регіонів; економічний розвиток регіонів та його динаміка; сформована структура регіонального виробництва; регіональні програми розвитку соціальної сфери; демографічна ситуація в регіоні; структура попиту на робочу силу; направленість регіональної освітньої політики; розгалуженість освітньої сфери регіону тощо.

The determinant value of intellectual capital for structural modernization of regional economy is substantiated in the article. It is found that the reasons for the need for structural modernization of the regional economy include: the change of value orientations in the system of consumer needs under the influence of mass social phenomena or the achievements of scientific and technological progress; qualitative changes in the material and technical base of production under the influence of intensification of innovative processes; the impact of market self-regulation processes; the impact of existing structural changes or structural changes that have occurred in the soap; global tendencies towards liberalization of foreign economic relations between states and others. It is outlined that the purpose of structural modernization of the regional economy is to accelerate the economic development of the regions, to increase the efficiency of regional economic activity and the standard of living of the population. It has been determined that the structural modernization of the regional economy is based on the inherent properties of a particular region and has certain related features, including: specificity of the economic, internal political, cultural, social sphere of life of the regions; factors and implementation of structural shifts in regional systems that have a synergistic effect with respect to shifts in different spheres of life in 
the region; existing established values and resources are an incentive mechanism for structural modernization of regions; a tendency towards a purposeful and permanent transition to more modern forms of economic development; rationality and evolution of the processes of structural modernization of regions, which is caused by the search for optimal ways of development of the regional economy, etc. The features on which structural modernization of the regional economy is based are revealed. As the current challenges prove the need to search for ways of activating the intellectual potential of the regions in order to ensure the structural modernization of the regional economy, the determinant value of the intellectual potential of the region in the structural modernization is justified. The factors of influence on the formation of intellectual capital of the regions are distinguished, among them: the natural resource potential of the regions; economic development of the regions and its dynamics; formed structure of regional production; regional social development programs; demographic situation in the region; structure of demand for labor; the focus of regional education policy; branching of the educational sphere of the region, etc.

Ключові слова: структурна модернізація регіональної економіки, інтелектуальний капітал, регіональна економіка, регіон, структурні зрушення, модернізація.

Key words: structural modernization of regional economy, intellectual capital, regional economy, region, structural changes, modernization.

\section{ПОСТАНОВКА ЗАВААННЯ}

Динаміка розвитку провідних країн світу впродовж останнього десятиліття свідчить про наявність складних внутрішньо-системних трансформацій як всередині національних економік та її регіонів, так і в рамках їх взаємодії на глобальному рівні. Активні процеси економічної інтеграції в поєднанні з тотальною інформатизацією економічного простору забезпечили стабільні темпи зростання прогресивних країн, однак наразі їх ефект згасає. Водночас помітна поляризація підходів у вирішенні глобальних проблем (світова торгівля, міграція, екологія тощо) разом із загостренням соціокультурних питань гуманітарного характеру сприяють розбалансуванню структури економік і створюють загрози виникнення майбутніх криз.

Діалектика поточного стану української економіки відзначається фрормуванням описаних раніше загроз цивілізаційного масштабу, які складають передумови поглиблення існуючих структурних проблем, водночас створюючи потенційні можливості та перспективні напрями їх вирішення. Більш того, обраний Україною євроінтеграційний курс розвитку вимагає якісно нових підходів у фрормуванні ключових принципів та напрямів провадження структурної модернізації регіонів України.

\section{АНА $\Lambda$ ОСТАНHIX АОС $\Lambda$ ІАЖЕНЬ ТА ПУБАІКАЦІЙ}

Модернізаційні аспекти розвитку економічних систем досліджували такі західні науковці: Г. Александер, Дж. Бейлі, Г. Марковіц, М. Міллер, Ф. Модільяні, М. Фрідмен, У. Шарп, Й. Шумпетер та інші дослідники.

Модернізаційні аспекти просторового розвитку, структурна модернізація регіональних господарських систем широко висвітлюється вітчизняними науковцями, серед яких необхідно відзначити науковий доробок: О. Амоши, Б. Буркинського, М. Бутка, С. Вовканича, А. Власюка, В. Гейця, Б. Данилишина, М. Долішнього, І. Дунаєва, В. Кулішова, П. Любченко, Ю. Макогона, М. Михальченка, М. Пашкевича, С. Пирожкова, С. Романюка, В. Сіденка, В. Симоненка, І. Сторонянської, С. Тульчинської, В. Чужикова, С. Штефрана, С. Шульца та багатьох інших.
Незважаючи на науковий пошук вчених, необхідно відзначити, що питання структурної модернізації регіональної економіки залишаються недостатньо розробленими та потребують подальших досліджень.

\section{META I ЗАВАAНHЯ CTATTI}

Метою статті виступає обгрунтування детермінуючого значення інтелектуального капіталу для здійснення структурної модернізації регіональної економіки.

Для досягнення поставленої мети в процесі дослідження було поставлено та вирішено такі завдання:

- визначено причини необхідності структурної модернізації регіональної економіки;

- окреслено ознаки, які притаманні структурній модернізації із урахуванням регіональних специфрічних наявних ресурсів та потенційних можливостей;

- виявлено особливості, на яких базується структурна модернізація регіональної економіки;

- обгрунтовано детермінуюче значення інтелектуального потенціалу регіону у структурній модернізації;

- визначено чинники впливу на фрормування інтелектуального потенціалу регіону.

\section{ВИК ААА ОСНОВНОГО МАТЕРІААУ АОС АІАЖЕННЯ}

Структурна модернізація систем різного рівня виступає загальносвітовою проблемою розвитку економічних систем. Науковці визначають актуальність та шляхи пошуку структурних зрушень економіки на різних рівнях.

До причин необхідності структурної модернізації регіональної економіки слід віднести таке:

- зміну ціннісних орієнтирів у системі споживчих потреб під впливом масових суспільних явищ або досягнень науково-технічного прогресу;

- якісні зміни матеріально-технічної бази виробництва під впливом інтенсифікації інноваційних процесів;

- вплив процесів ринкового саморегулювання;

- вплив наявних структурних зрушень або структурних зрушень, які мали місце у милому;

— циклічні процеси економічної системи (від дрібних кон'юнктурних коливань до економічних криз глобального масштабу); 
- інформатизацію та діджиталізацію глобального економічного простору;

— глобальні тенденції до лібералізації зовнішньоекономічних взаємодій між державами тощо.

Модернізація регіональної економіки із притаманними їй принципами, підходами та інструментами проводиться за рахунок структурної політики держави, але кожен регіон із урахуванням наявних ресурсів та потенціалу вибудовує власний напрям та визначає акценти щодо використання інструментарію структурної модернізації регіону, його напрями та цілі. Водночас, структурна модернізація регіональної економіки виступає складовою модернізації економіки країни.

Мета структурної модернізації регіональної економіки полягає у прискоренні економічного розвитку регіонів, підвищенні ефективності регіональної господарської діяльності та рівня життя населення.

Структурна модернізація регіональної економіки спирається на притаманні властивості конкретного регіону та має певні пов'язані з цим ознаки, серед яких:

- специфіка економічної, внутрішньополітичної, культурної, соціальної сфери життя регіонів;

- фрактори здійснення структурних зрушень регіональних систем, що мають синергійний ефект по відношенню до зрушень у різних сферах життя регіону;

- наявні усталені цінності та ресурси, які виступають спонукальним механізмом здійснення структурної модернізації регіонів;

- тенденції щодо цілеспрямованого та постійного переходу на більш сучасні форми економічного розвитку;

- раціональність та еволюційність процесів структурної модернізації регіонів, що зумовлено пошуком оптимальних шляхів розвитку регіональної економіки;

- стратегічна спрямованість планів та програм регіонального розвитку на довгострокову перспективу та постійний розвиток регіону у разі залучення певних механізмів та інструментів їх досягнення;

- притаманний характер динамічності економічного розвитку, що являється рушійною силою регіональних систем;

- специфічні внутрішні взаємозв'язки та процеси, що включають у себе партнерські, комерційні, державно-приватні та інші різновиди;

- модернізаційні процеси в регіонах $€$ частиною комплексної структурної модернізації країни загалом.

Водночас структурна модернізація регіональної економіки базується на:

- виявленні базових галузей та об'єднань на території регіону, модернізація яких спроможна дати синергійний ефект для регіонального економічного розвитку;

- налагодженні більш тісних, а також нових взаємозв'язків між суб'єктами господарювання регіонів та поза його межами; гіоні;

- зміні структури галузевих співвідношень у ре-

- розвитку соціальної, інноваційної, інфрормаційної та економічної інфраструктури регіонів;

- зміні у структурі управління економічним розвитком через спрямування зусиль на управління структурною модернізацію;
- диверсисрікації господарської діяльності в регіоні;

- раціоналізації співвідношень між різновидами галузей у регіональному валовому продукті;

- переході до інноваційної моделі розвитку економіки регіонів;

— переформатуванні механізму перерозподілу існуючих ресурсів тощо.

Структурна модернізація регіональної економіки супроводжується просторовим розвитком регіонів та забезпечується певними принципами її проходження [3]:

- формування сприятливого регіонального середовища для здійснення структурних зрушень;

- вибір найбільш оптимальної траєкторії розвитку з багатьох наявних;

- прийняття неминучості економічних рецесій у розвитку регіональної економіки, що обумовлено циклічним характером розвитку;

- багатополярність у дотриманні інтересів населення регіонів;

— інформаційна публічність зрушень у регіональній економіці;

- еволюційна революційність;

- суб'єктна відносність.

Погоджуючись із думкою багатьох вчених $[1 ; 2 ; 6$; 7], зрозуміло, що детермінуючим фрактором структурної модернізації виступає інтелектуальний потенціал регіонів. Так, наприклад, поштовхом та основою структурної модернізації регіональної економіки, на думку О.В. Попело, виступають інноваційні регіональні структури, серед яких особливе місце займають підприємницькі інноваційні кластери. Як визначає авторка, такі кластери "володіють потужним потенціалом для зростання технологічного рівня виробництва, створюють сприятливі умови для активного впровадження інновацій; в їх рамках поєднуються інтереси регіональних господарських систем, реалізується людський потенціал і науковоосвітні домінанти, суттєво прискорюються процеси формування секторальних сегментів інноваційної моделі економіки..." [4, с. 223]. Погоджуючись з авторкою, що підприємницькі інноваційні кластери безумовно спроможні впливати та здійснювати структурну модернізацію регіональної економіки, хочемо зосередити увагу також на необхідності забезпечення умов розвитку таких кластерів, а також підтримці та розвитку інтелектуального потенціалу регіонів.

Проведення модернізаційних реформ у регіонах у напрямі структурної модернізації регіональної економіки спроможна реалізовуватися за рахунок підприємницьких інноваційних кластерів. Але водночас потрібно запроваджувати підтримку освіти, науки, інноваційнотехнологічну діяльність тощо. Без запровадження підтримки освітньої та наукової сфери неможливо будувати підприємницькі інноваційні кластери.

Незважаючи на те, що інтелектуальний капітал у наш час визначає розвиток регіонів, охоплюючи всю матеріальну і фрінансову структуру економіки, поки що залишається проблема його стимулювання та фінансування.

В Україні досі спостерігається стабільний відтік висококваліфікованих фахівців, як правило, зі своїми інноваційними напрацюваннями, а також старіння на- 
укових кадрів, зменшення результативності наукового пошуку унаслідок хронічного недофінсування та старої матеріальної бази наукових установ. Але сучасні виклики доводять необхідність пошуку напрямів активізації інтелектуального потенціалу регіонів для забезпечення структурної модернізації регіональної економіки.

Необхідно зауважити, що "на мезо- та макрорівні інтелектуальний капітал представляє собою сукупність особистих здібностей, реалізація яких зумовлює можливість фрормування конкурентних переваг інтелектуально-інноваційної системи регіонів за допомогою якісного оновлення виробництва, рефрормування ринку праці та відносин інтелектуальної власності, а також вдосконалення форм міжрегіональної співпраці" [5, с. 58].

На формування інтелектуального капіталу регіонів впливають:

— природно-ресурсний потенціал регіонів;

- економічний розвиток регіонів та його динаміка; - сорормована структура регіонального виробництва;

- регіональні програми розвитку соціальної сорери;

- демографічна ситуація в регіоні;

- структура попиту на робочу силу;

- направленість регіональної освітньої політики;

- розгалуженість освітньої сфери регіону тощо.

\section{ВИСНОВКИ}

Отже, проведене дослідження дає можливість стверджувати, що головною метою структурної модернізації регіональної економіки виступає прискорення економічного розвитку регіонів, підвищення ефективності регіональної господарської діяльності та рівня життя населення. Окреслення причин необхідності структурної модернізації регіональної економіки, що лежать у площині як регіонального розвитку, так і аспектів національної економіки загалом дало можливість: по-перше, окреслити ознаки, які притаманні структурній модернізації із урахуванням регіональних специфрічних наявних ресурсів та потенційних можливостей; по-друге, виявити особливості,на яких базується структурна модернізація регіональної економіки; по-третє, обгрунтувати детермінуюче значення інтелектуального потенціалу регіону у структурній модернізації. Із урахуванням детермінуючого значення інтелектуального потенціалу щодо ефективності структурної модернізації регіональної економіки виокремлено чинники впливу на його формування.

Здійснення структурної модернізації економіки регіонів із урахуванням використання інтелектуальних ресурсів сприятиме підвищенню конкурентоспроможності регіонів, підвищенню ефективності їх господарської діяльності тощо.

Подальших наукових розвідок вимагають питання розроблення концептуальних засад модернізації структурних перетворень у економіці регіонів України в контексті капіталізації інтелектуального капіталу.

\section{Література:}

1. Бутко М.П., Попело О.В. Інтелектуальний капітал як чинник модернізації регіонального економічного простору: монографрія. Ніжин, Аспект-Поліграфр, 2014. $372 \mathrm{c}$.

2. Детермінанти розвитку національного господарства: монографрія. за заг. ред. П.В. Круша. Київ, НТУУ "КПІ", 2014. 276 c.

3. Пашкевич М.С., Лисунець К.П. Принципи модернізації економіки регіонів України в аспекті сучасної регіональної політики. Ефективна економіка. 2014. № 10. URL: http://nbuv.gov.ua/UJRN/efek_2014_10_7 (дата звернення: 20.01.2020).

4. Попело О.В. Інноваційна активність як домінуюча складова модернізації продуктивних сил регіону. Проблеми і перспективи економіки та управління. № 4 (4), 2015. С. $222-229$.

5. Тульчинська С.О. Інтелектуально-інноваційна модернізація економіки України: теоретико-методологічні аспекти: монографрія. Київ, НТУУ "КПІ", 2009. $488 \mathrm{c.}$

6. Тульчинська С.О. Перспективи та домінанти розвитку інтелектуально-інноваційної системи регіонів України: монографрія. Херсон, Ви-во "ПП Вишемирський B.C.", 2014. 210 c.

7. Тульчинський Р.В. Детермінанти становлення нового регіоналізму: теорія, методологія, практика: монографрія. Херсон, Вид-во "ПП Вишемирський В.С.", 2018. 400 c.

References:

1. Butko, M.P. and Popelo, O.V. (2014), Intelektual'nyj kapital iak chynnyk modernizatsii rehional'noho ekonomichnoho prostoru [Intellectual capital as a factor of modernization of regional economic space], AspektPolihraf, Nizhyn, Ukraine.

2. Krush, P.V. (2014), Determinanty rozvytku natsional'noho hospodarstva [Determinants of the development of the national economy], NTUU "KPI", Kyiv, Ukraine.

3. Pashkevych, M.S. and Lysunets', K.P. (2014), "Principles of modernization of economy of regions of Ukraine in the aspect of modern regional policy", Efektyvna ekonomika, vol. 10, available at: http://nbuv.gov.ua/ UJRN/efek_2014_10_7 (Accessed 20 January 2020).

4. Popelo, O.V. (2015), "Innovative activity as a dominant component of modernization of the productive forces of the region", Problemy i perspektyvy ekonomiky ta upravlinnia, vol. 4, no. 4, pp. 222-229.

5. Tul'chyns'ka, S.O. (2009), Intelektual'no-innovatsijna modernizatsiia ekonomiky Ukrainy: teoretykometodolohichni aspekty [Intellectual-innovative modernization of the Ukrainian economy: theoretical and methodological aspects], NTUU "KPI", Kyiv, Ukraine.

6. Tul'chyns'ka, S.O. (2014), Perspektyvy ta dominanty rozvytku intelektual'no-innovatsijnoi systemy rehioniv Ukrainy [Perspectives and dominants of development of the intellectually innovative system of the regions of Ukraine], Vyd-vo "PP Vyshemyrs'kyj V.S.", Kherson, Ukraine.

7. Tul'chyns'kyj, R.V. (2018), Determinanty stanovlennia novoho rehionalizmu: teoriia, metodolohiia, praktyka [Determinants of the emergence of a new regionalism: theory, methodology, practice], Vyd-vo "PP Vyshemyrs'kyj V.S.", Kherson, Ukraine.

Cтаття надійшла до редакиї 02.03.2020p. 